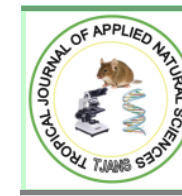

Tropical Journal of Applied Natural Sciences

Trop. J. Appl. Nat. Sci., 2(2): 64-72 (2018)

ISSN: $2449-2043$

https://doi.org/10.25240/TJANS.2018.2.2.09

\title{
An Assessment of Water Quality Parameters and Trace Metal Contents of Two Surface Drinking Water in Nise, Anambra State, Nigeria
}

\author{
Keziah Nwamaka Ibemenuga * and Chikodili Chisom Egbosi
}

Department of Biological Sciences, Chukwuemeka Odumegwu Ojukwu University, P.M.B.02, Uli, Anambra State, Nigeria.

*Corresponding author's E-mail: jesusvesselofhonour@yahoo.com; Phone no: +2348126421299

\begin{abstract}
Due to introduction of pollutants in surface drinking water bodies, man has been exposed to several health problems. As a result, the study investigates the status of water quality parameters and trace metal contents of the streams in Nise. The study on the water quality and trace metal contents of Iyiocha Stream and Obizi Stream in Nise, Awka South Local Government Area, Anambra State, Nigeria was conducted from April to July, 2017. Surface drinking water were taken fortnightly from the streams with standard procedures. The samples were conveyed to the Biological Science laboratory, Chuwkuemeka Odumegwu Ojukwu University, Uli where they were analyzed for $\mathrm{pH}$, turbidity, total hardness, alkalinity, biochemical oxygen demand and presence of trace metals such as lead, copper, manganese, zinc and sodium. Results obtained from the analysis showed that the highest hardness mean value of $236.00 \pm 14.00 \mathrm{mg} / \mathrm{l}$ was recorded in May in Iyiocha Stream. Hardness values recorded across the study months in Iyiocha and Obizi Streams exceeded the WHO standard limits. The $\mathrm{pH}$ of Obizi Stream was slightly acidic with an average $\mathrm{pH}$ value of $6.20 \mathrm{mg} / \mathrm{l}$. The $\mathrm{pH}$ values for Iyiocha Stream $(6.68 \pm 0.22)$ is within the WHO permissible limits. Turbidity of both Streams corresponds with the WHO acceptable limits. The value for lead in both streams exceeded the WHO permissible limits. Similarly, the mean value for sodium concentration in the streams was above the WHO acceptable limits. The present study showed that there was no significant difference $(\mathrm{P}>0.05)$ between water samples from Obizi and Iyiocha Streams using unpaired student's t-test. Monitoring of quality and quantity of streams is needed for good quality water supply to the public.
\end{abstract}

Original Research Article

Received: $19^{\text {th }}$ Jan., 2018

Accepted: $09^{\text {th }}$ Feb., 2018

Published: $14^{\text {th }}$ Mar., 2018

Keywords:

Assessment

Water quality parameters

Trace metals

Surface drinking water.

\section{INTRODUCTION}

$\mathrm{W}$ ater is an essential natural resource for sustainability of life on earth. Water is a naturally occurring substance needed for activities such as industrial and agricultural processes, cooking, drinking, waste disposal and human recreation (Izonfus and Bariweni, 2001). Man cannot live without water which fills the body fluids lost through normal physiological activities such as respiration, perspiration, urination, etc (Murray et al., 2003).

Drinking water is got from two main sources, surface water (streams, springs, rivers, lakes, etc) and groundwater (borehole water and well water) (McMurray and Fay, 2004). Lotic ecosystems such as streams play vital role in water cycle, groundwater 
recharge and habitats for aquatic animals and plants. Contamination of these streams lead to poor water quality. The quality of water which refers to the chemical, physical and biological characteristics of water (Chitmanat and Traichaiyaporn, 2010) is a vital concern for mankind since it is directly linked with human welfare. Water quality evaluation and management is of ecotoxicological importance because poor water quality continues to constitute danger to human health. Today contaminated water has been reported to kill more people than cancer, AIDS (Acquired Immune Deficiency Syndrome), war or even accident (Rail, 2000; WHO, 2011). Of the wide diversity of pollutants affecting water aquatic bodies, heavy metals are of particular interest due to their being harmful in low concentrations. The study of behaviour of trace metals may be sensitive indicators for pollution levels in the water environment, thus accurate determinations of trace metals and other physical and chemical parameters, in aquatic environment are of ultimate importance for water quality monitoring.

Studies on surface water contamination in Nigeria include Nwodo et al. (2011), Anake et al. (2014) and Ojutiku et al. (2014). However, no such study has been conducted in Iyiocha Stream and Obizi Stream. Hence the aim of this study is to evaluate water quality

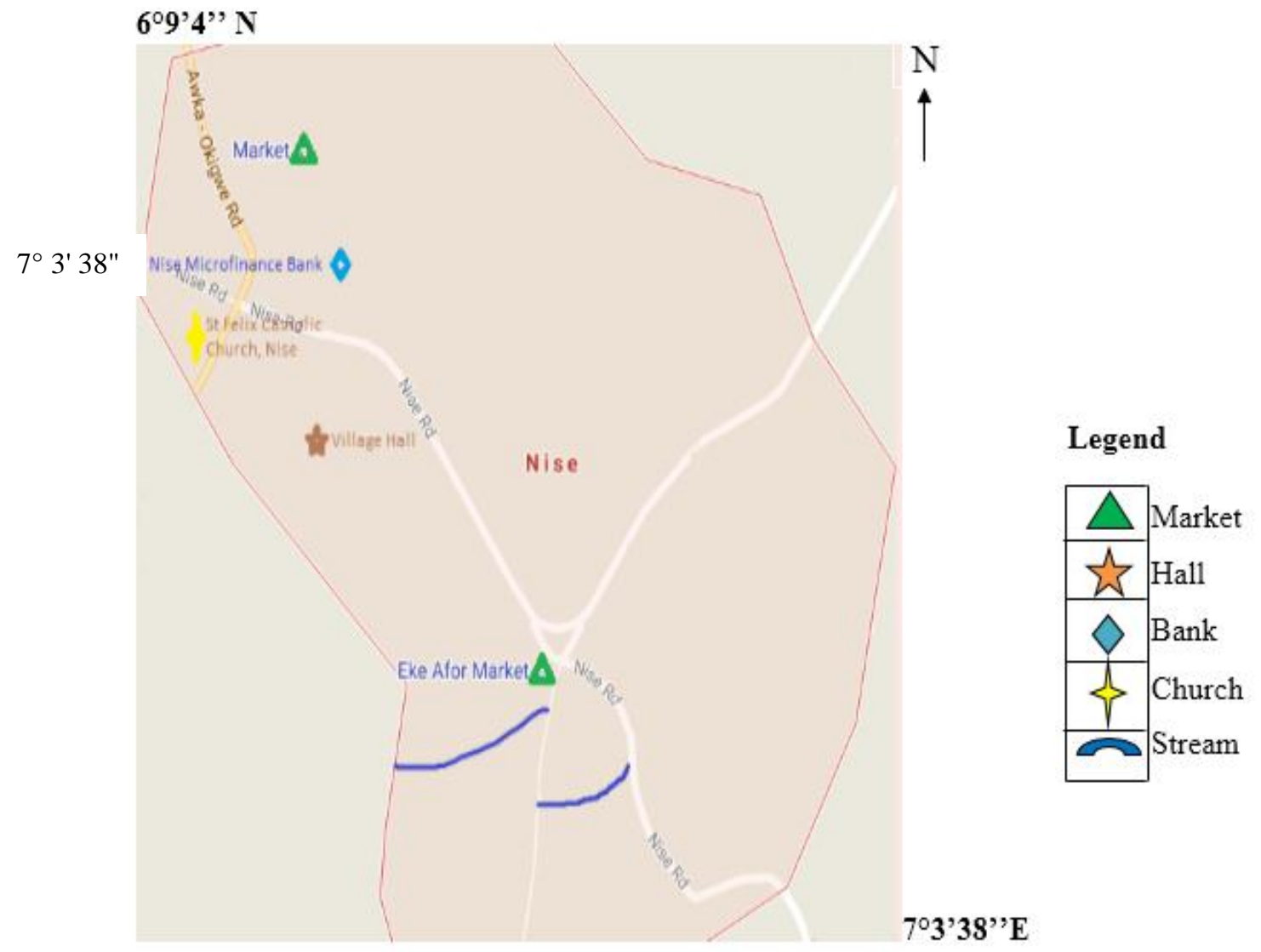

parameters and trace metal contents of Obizi and Iyiocha Streams in Nise, Awka South Local Government Area of Anambra State, Nigeria, comparing the parameters with WHO water quality standard to ascertain their portability.

\section{MATERIALS AND METHODS \\ Description of Sample Collection Site}

This study was carried out at both 'Iyiocha' and 'Obizi' Streams in Nise, a town in Awka South L.G.A of Anambra State, Nigeria. Iyiocha Stream lies between the latitude $6^{\circ} 9^{\prime} 4^{\prime \prime}$ North, 7 $3^{\prime} 38^{\prime \prime}$ East (Fig.1). It has a characteristically tropical climate with predominantly rainforest, annual rainfall of $1952 \mathrm{~mm}$ and average daily atmospheric temperature of $26{ }^{\circ} \mathrm{C}$. It has two distinct seasons, the dry season and wet season. Dry season starts from November to March while the wet season cut across April to October. The Stream rises from Ara, flows from Umuawulu through Agulu and empties into Agulu Lake.

Obizi Stream also lies within the same latitude $6^{\circ} 9^{\prime} 4^{\prime \prime}$ North, $7^{\circ} 3^{\prime} 38^{\prime \prime}$ East (Fig.1). The stream rises from Ara, flows from Umuawulu through Agulu and empties into Agulu Lake. It runs through Obizi forest with shrubs and trees Human artivities such as swimming, farming, wasl $6^{\circ} 9^{\prime} 4 " \mathrm{~N} \quad$ jitter-leaf, breadfruit and clothing occur arounu ure stream.

Figure 1: Map showing the Study Area

Source: Google Map (2017). 


\section{Collection of Water Samples}

Water samples for water quality parameters and trace metal content analysis were collected fortnightly between 07.00 and $11.00 \mathrm{hrs}$ from the study stream in plastic bottles. The bottles were sterilized with $70 \%$ ethanol, cleaned and rinsed three times with sample prior to filling. The samples were filled into the sampling bottles after rinsing, then capped, labeled accordingly and returned to plastic bag. The samples were carried to the Biological Science Laboratory, Chukwuemeka Odumegwu Ojukwu University, Uli for analysis.

\section{Water and Data Analysis}

\section{Water analysis}

The samples collected were analyzed for $\mathrm{pH}$, turbidity, total hardness, alkalinity, and biochemical oxygen demand. The $\mathrm{pH}$ was measured by electrometric method using laboratory $\mathrm{pH}$ meter Hanna model H1991300. The total hardness and alkalinity of the samples were determined by titrimetric method using standard procedures described by American Public Health Association, APHA (1998) turbidity meter of model HACH 200Q was used to determine the turbidity of the samples and biochemical oxygen demand was determined by Winkler's method.

\section{Methods for trace metal analysis}

Trace metal analysis was determined using Spectrophotometeric method prescribed by APHA (1995).

\section{Data analysis}

Data obtained were statistically analyzed using student's t-test, correlation coefficient and analysis of variance (ANOVA) to ascertain if there were significant differences.

\section{RESULTS}

\section{Monthly variations in physico-chemical parameters of Obizi Stream and Iyiocha Stream}

Table 1 shows the physico-chemical parameters of Obizi Stream and Iyiocha Stream while Table 2 shows comparison of mean physico-chemical parameters with WHO standards for safe drinking water. The overall mean $\mathrm{pH}$ value $(6.68 \pm 0.22)$ recorded for Iyiocha Stream was higher than the overall mean $(6.20 \pm 0.43)$ recorded for Obizi Stream with a range of 6.46-6.90 and 5.77-6.63 respectively. There was slight variation in the level of $\mathrm{pH}$ between the two Streams (Fig. 2).

Turbidity varied widely over the months in Iyiocha Stream compared to narrow variations observed in Obizi Stream. The highest mean turbidity value of $46.00 \pm 2.99$ NTU was recorded in April (range 43.01 - 48.99 NTU) while the lowest value $3.00 \pm 0.00 \mathrm{NTU}$ was recorded in July. For Obizi Stream, the highest and lowest mean turbidity values occurred in April (18.00 \pm 6.00 NTU, $12.00-24.00 \mathrm{NTU})$ and July $(6.00 \pm 0.99 \mathrm{NTU}, 5.01-$ $6.99 \mathrm{NTU})$. The overall mean turbidity value was higher in Iyiocha Stream than in Obizi Stream (Table 1). The mean monthly variation in hardness in the two Streams from April to July is shown in Table 1. The overall mean monthly hardness value of $132.80 \pm 13.42 \mathrm{mg} / \mathrm{l}$ (range $119.38 \mathrm{mg} / \mathrm{l}$ ) and $94.65 \pm 7.52 \mathrm{mg} / \mathrm{l}$ (range 87.13-102.17 $\mathrm{mg} / \mathrm{l})$ were obtained in Obizi and Iyiocha Streams respectively. Hardness varied in both Streams. It increased progressively from April $(100.00 \pm 20.00 \mathrm{mg} / \mathrm{l})$ to May $(141.00 \pm 9.00 \mathrm{mg} / \mathrm{l})$, decreased in June $(126.00 \pm 6.00 \mathrm{mg} / \mathrm{l})$ before increasing again in July $(164.00 \pm 35.00 \mathrm{mg} / \mathrm{l})$ in Obizi Stream (Fig. 3). In Iyiocha Stream, hardness peaked in May and crashed in June with further decrease in July. Generally, higher mean hardness values occured in Obizi Stream over the study months except in May. The highest mean value of $236.00 \pm 14.00 \mathrm{mg} / \mathrm{l}$ was recorded in May in Iyiocha Stream. Alkalinity fluctuated in both Streams over the study period. Higher mean alkalinity values occurred in most of the months in Iyiocha Stream. There was variation in the biological oxygen demand concentration obtained in the study. The highest and lowest mean values of $602.00 \pm 18.00 \mathrm{mg} / \mathrm{l}$ (range $584.00-620.00$ $\mathrm{mg} / \mathrm{l})$ and $506.00 \pm 4.00$ (range $502-510 \mathrm{mg} / \mathrm{l}$ ) were recorded in the months of July and June respectively for Obizi Stream while the highest and lowest mean values in Iyiocha Stream was recorded as $182.00 \pm 2.00 \mathrm{mg} / \mathrm{l}$ (range $180.00-184.00 \mathrm{mg} / \mathrm{l}$ ) and $133.00 \pm 47.99$ (range $85.01-180.99 \mathrm{mg} / \mathrm{l}$ ) in the months of May and June respectively 
Table 1: The mean $( \pm$ S.E $)$ values in the physico-chemical parameters of Obizi Stream and Iyiocha Stream.

\begin{tabular}{|c|c|c|c|c|c|c|c|c|c|c|}
\hline \multirow[t]{2}{*}{ Parameters } & \multicolumn{5}{|c|}{ Obizi Stream } & \multicolumn{5}{|c|}{ Iyiocha Stream } \\
\hline & April & May & June & July & Overall & April & May & June & July & Overall \\
\hline \multirow[t]{2}{*}{ pH } & $6.68 \pm 0.28$ & $7.06 \pm 0.53$ & $5.96 \pm 0.42$ & $5.08 \pm 0.07$ & $6.20 \pm 0.43$ & $6.58 \pm 0.03$ & $6.40 \pm 0.35$ & $7.41 \pm 0.42$ & $6.33 \pm 0.21$ & $6.68 \pm 0.22$ \\
\hline & $(6.40-6.96)$ & $(6.53-7.59)$ & (5.54-6.38) & $(5.01-5.15)$ & $(5.77-6.63)$ & $(6.55-6.61)$ & $(6.05-6.75)$ & $(6.99-7.83)$ & $(6.12-6.54)$ & $(6.46-6.90)$ \\
\hline \multirow{3}{*}{$\begin{array}{l}\text { Turbidity } \\
\text { (NTU) }\end{array}$} & $18.00 \pm 6.00$ & $13.00 \pm 3.00$ & $12.50 \pm 5.50$ & $6.00 \pm 0.99$ & $12.34 \pm 2.46$ & $46.00 \pm 2.99$ & $5.50 \pm 0.50$ & $6.00 \pm 2.99$ & $3.00 \pm 0.00$ & $15.13 \pm 1.02$ \\
\hline & $(12.00-24.00)$ & $(10.00-16.00)$ & (7.00-18.00) & $(5.01-6.99)$ & $(9.88-14.80)$ & $\begin{array}{l}(43.01- \\
48.99)\end{array}$ & $(5.00-6.00)$ & (3.01-8.99) & $(3.00-3.00)$ & \\
\hline & & & & & & & & & & 16.75) \\
\hline \multirow{2}{*}{$\begin{array}{l}\text { Hardness } \\
(\mathrm{mg} / \mathrm{l})\end{array}$} & $100.00 \pm 20.00$ & $141.00 \pm 9.00$ & $126.00 \pm 6.00$ & $164.00 \pm 35.00$ & $132.80 \pm 13.42$ & $26.00 \pm 4.00$ & $236.00 \pm 14.00$ & $92.00 \pm 7.99$ & $24.60 \pm 4.10$ & $94.65 \pm 7.52$ \\
\hline & $(80.00-120.00)$ & $\begin{array}{l}(132.00- \\
149.00)\end{array}$ & $\begin{array}{l}(120.0- \\
132.0)\end{array}$ & $\begin{array}{l}(129.00- \\
199.00)\end{array}$ & $\begin{array}{l}(119.38- \\
146.22)\end{array}$ & $\begin{array}{l}(22.03- \\
30.00)\end{array}$ & $\begin{array}{l}(222.00- \\
250.00)\end{array}$ & (84.01-99.99) & $\begin{array}{l}(20.50- \\
28.70)\end{array}$ & $(87.1-102.1)$ \\
\hline \multirow{3}{*}{$\begin{array}{l}\text { Alkalinity } \\
\text { (mg/l) }\end{array}$} & $20.00 \pm 8.00$ & $13.75 \pm 1.25$ & $16.25 \pm 3.75$ & $10.00 \pm 2.00$ & $15.00 \pm 2.11$ & $10.00 \pm 2.00$ & $19.35 \pm 0.65$ & $16.90 \pm 1.40$ & $17.50 \pm 1.30$ & $15.94 \pm 1.77$ \\
\hline & $(12.00-28.00)$ & $(12.50-15.00)$ & $\begin{array}{l}(12.50- \\
20.00)\end{array}$ & $(8.00-12.00)$ & $(12.89-17.11)$ & $(8.00-12.00)$ & $(18.70-20.00)$ & $(15.50-18.30)$ & $\begin{array}{l}(16.20- \\
18.80)\end{array}$ & (14.17- \\
\hline & & & & & & & & & & 17.71) \\
\hline \multirow[t]{2}{*}{ BOD (mg/l) } & $524.00 \pm 14.00$ & $524.00 \pm 6.00$ & $506.00 \pm 4.00$ & $602.00 \pm 18.00$ & $539.00 \pm 21.41$ & $166.00 \pm 6.00$ & $182.00 \pm 2.00$ & $133.00 \pm 47.99$ & $142.00 \pm 2.00$ & $155.75 \pm 0.04$ \\
\hline & $(510.00-538.00)$ & $\begin{array}{l}(518.00- \\
530.00)\end{array}$ & $\begin{array}{l}(502.0- \\
510.0)\end{array}$ & $\begin{array}{l}(584.00- \\
620.00)\end{array}$ & $\begin{array}{l}(517.59- \\
560.41)\end{array}$ & $\begin{array}{l}(160.0- \\
172.0)\end{array}$ & $(180.0-184.0)$ & $(85.01-180.99)$ & $\begin{array}{l}(140.0- \\
144.0)\end{array}$ & $\begin{array}{l}(155.7- \\
155.7)\end{array}$ \\
\hline
\end{tabular}


Table 2: Mean monthly values of the physico-chemical parameters of Obizi Stream and Iyiocha Stream compared with WHO standards for safe drinking water.

\begin{tabular}{|c|c|c|c|}
\hline Parameters & Obizi Stream & Iyiocha Stream & Reference Value (WHO Std) (2003) \\
\hline pH & $\begin{array}{l}6.20 \pm 0.43 \\
(5.77-6.63)\end{array}$ & $\begin{array}{l}6.68 \pm 0.22 \\
(6.46-6.90)\end{array}$ & $\leq 6.5-8.5$ \\
\hline Turbidity (NTU) & $\begin{array}{l}12.34 \pm 2.46 \\
(9.88-14.80)\end{array}$ & $\begin{array}{l}15.13 \pm 1.02 \\
(13.51-16.75)\end{array}$ & $\leq 200$ \\
\hline Hardness (mg/l) & $\begin{array}{l}132.80 \pm 13.42 \\
(119.38-146.22)\end{array}$ & $\begin{array}{l}94.65 \pm 7.52 \\
(87.13-102.17)\end{array}$ & $\leq 70$ \\
\hline Alkalinity (mg/l) & $\begin{array}{l}15.00 \pm 2.11 \\
(12.89-17.11)\end{array}$ & $\begin{array}{l}15.94 \pm 1.77 \\
(14.17-17.71)\end{array}$ & NA \\
\hline BOD (mg/l) & $\begin{array}{l}539.00 \pm 21.41 \\
(517.59-560.41)\end{array}$ & $\begin{array}{l}155.75 \pm 0.04 \\
(155.71-155.79)\end{array}$ & NA \\
\hline
\end{tabular}

$\mathrm{NA}=$ Not Available.

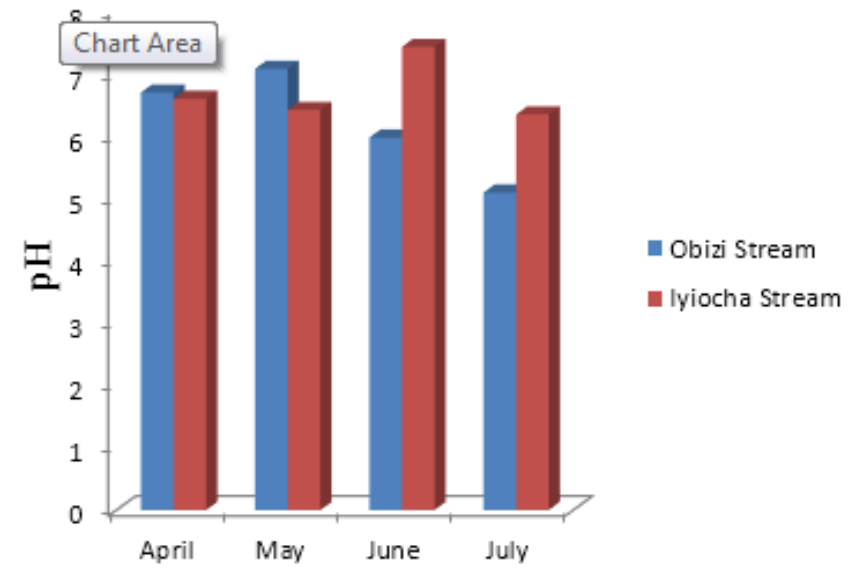

Figure 2: Mean monthly variations in $\mathrm{pH}$ in Obizi Stream and Iyiocha Stream.

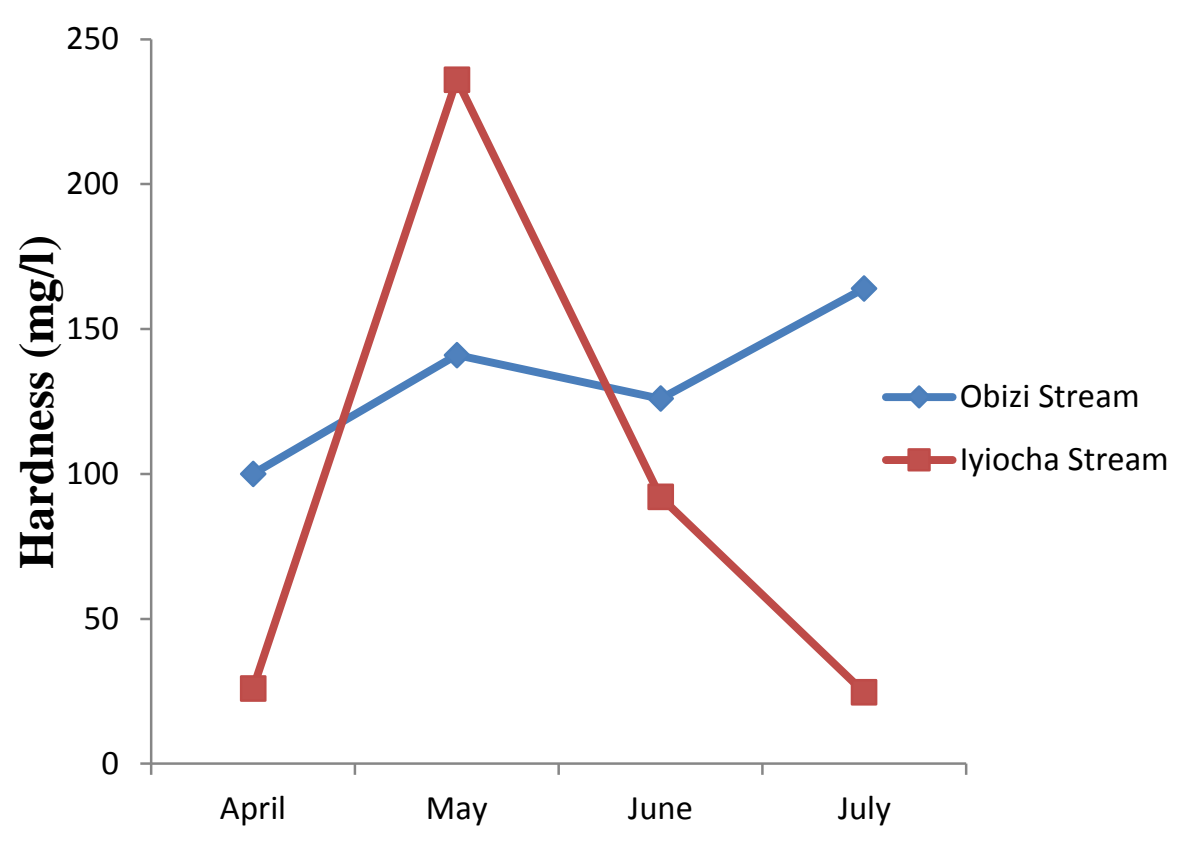

Figure 3: Mean monthly variations in hardness in Obizi Stream and Iyiocha Stream. 


\section{Mean monthly variations in trace metal contents of Obizi Stream and Iyiocha Stream}

The results of mean monthly trace metal contents of Obizi Stream and Iyiocha Stream is presented in Table 3 and its comparison with WHO standards for safe drinking water is shown in Table 4. Water samples of both streams were analyzed for $\mathrm{Pb}, \mathrm{Cu}, \mathrm{Mn}, \mathrm{Zn}$ and $\mathrm{Na}$. The studied trace metal concentrations in Obizi Stream were ranked as follows $\mathrm{Na}>\mathrm{Pb}>\mathrm{Zn}>\mathrm{Cu}>\mathrm{Mn}$. For Iyiocha Stream, the rank of the average heavy metal concentration were as follows $\mathrm{Na}>\mathrm{Zn}>\mathrm{Mn}>\mathrm{Pb}>\mathrm{Cu}$, with sodium having the highest concentration and copper the lowest concentration. Lead content varied widely in Obizi stream and narrowly in Iyiocha Stream (Fig. 4), while $12.09 \pm 1.68 \mathrm{mg} / \mathrm{l}$ was the highest mean value obtained in Obizi Stream in April, $0.33 \pm 0.55$ was the highest value recorded in Iyiocha Stream in April. The overall mean value of lead recorded during the study was higher in Obizi Stream $(5.04 \pm 2.60 \mathrm{mg} / \mathrm{l})$ compared to lower overall mean value of $0.21 \pm 0.04 \mathrm{mg} / \mathrm{l}$ recorded in Iyiocha Stream. The overall mean concentration of copper was higher $(1.16 \pm 0.56 \mathrm{mg} / 1$ range $0.06 \pm 1.72 \mathrm{mg} / \mathrm{l})$ in Obizi Stream and lower $(0.07 \pm 0.04 \mathrm{mg} / \mathrm{l}$, range 0.02 $0.10 \mathrm{mg} / \mathrm{l})$ in Iyiocha Stream. Manganese occurred in all the months in Iyiocha Stream with highest value $(0.39 \pm 0.13 \mathrm{mg} / \mathrm{l})$ in April. In Obizi Stream, it was recorded in all the months with the exception of July (Table 2). The highest mean value $(0.33 \pm 0.04 \mathrm{mg} / \mathrm{l}$, range $0.29-0.37 \mathrm{mg} / \mathrm{l})$ was obtained in May. The concentration of zinc fluctuated in both streams over the study period as shown in (Fig. 5). Sodium concentration was higher $(50.93 \pm 9.28 \mathrm{mg} / \mathrm{l})$ in Obizi Stream and lower $(15.30 \pm 3.12 \mathrm{mg} / \mathrm{l})$ in Iyiocha Stream.

Table 3: Mean $( \pm$ S.E. $)$ monthly variations in trace metal contents of Obizi Stream and Iyiocha Stream.

\begin{tabular}{|c|c|c|c|c|c|c|c|c|c|c|}
\hline \multicolumn{6}{|c|}{ Obizi Stream } & \multicolumn{5}{|c|}{ Iyiocha Stream } \\
\hline Parameters & April & May & June & July & Overall & April & May & June & July & Overall \\
\hline \multirow[t]{2}{*}{ Lead (mg/l) } & $12.09 \pm 1.68$ & $5.52 \pm 1.51$ & $2.46 \pm 0.77$ & $0.10 \pm 0.02$ & $5.04 \pm 2.60$ & $0.33 \pm 0.05$ & $0.20 \pm 0.08$ & $0.14 \pm 0.04$ & $0.16 \pm 0.01$ & $0.21 \pm 0.04$ \\
\hline & (10.41-13.77) & $(4.01-7.03)$ & $(1.69-3.23)$ & $(0.08-0.12)$ & $(2.44-7.64)$ & $(0.28-0.38)$ & $(0.12-0.28)$ & $(0.10-0.18)$ & $(0.15-0.17)$ & $(0.17-0.25)$ \\
\hline \multirow[t]{2}{*}{ Copper (mg/l) } & $2.46 \pm 0.21$ & $1.67 \pm 0.45$ & $0.50 \pm 0.50$ & $0.00 \pm 0.00$ & $1.16 \pm 0.56$ & $0.02 \pm 0.01$ & $0.19 \pm 0.16$ & $0.03 \pm 0.01$ & $0.04 \pm 0.01$ & $0.07 \pm 0.04$ \\
\hline & $(2.25-2.67)$ & $(1.22-2.12)$ & $(0.00-1.00)$ & $(0.00-0.00)$ & $(0.06-1.72)$ & $(0.01-0.03)$ & $(0.03-0.35)$ & $(0.02-0.04)$ & $(0.03-0.05)$ & $(0.02-0.10)$ \\
\hline \multirow[t]{2}{*}{ Manganese (mg/l) } & $0.22 \pm 0.08$ & $0.33 \pm 0.04$ & $0.11 \pm 0.03$ & $0.00 \pm 0.00$ & $0.17 \pm 0.07$ & $0.39 \pm 0.13$ & $0.23 \pm 0.03$ & $0.27 \pm 0.03$ & $0.22 \pm 0.01$ & $0.28 \pm 0.05$ \\
\hline & $(0.14-0.30)$ & $(0.29-0.37)$ & $(0.08-0.14)$ & $(0.00-0.00)$ & $(0.10-0.24)$ & $(0.26-0.52)$ & $(0.20-0.26)$ & $(0.24-0.30)$ & $(0.21-0.23)$ & $(0.23-0.33)$ \\
\hline \multirow[t]{2}{*}{ Zinc (mg/l) } & $1.97 \pm 0.29$ & $1.89 \pm 0.66$ & $2.48 \pm 0.75$ & $0.00 \pm 0.00$ & $1.59 \pm 0.51$ & $1.39 \pm 0.14$ & $0.14 \pm 0.01$ & $0.19 \pm 0.01$ & $0.16 \pm 0.01$ & $0.47 \pm 0.27$ \\
\hline & $(1.68-2.26)$ & $(1.23-2.55)$ & $(1.73-3.23)$ & $(0.00-0.00)$ & $(1.08-2.10)$ & $(1.25-1.53)$ & $(0.13-0.15)$ & $(0.18-0.20)$ & $(0.15-0.17)$ & $(0.20-0.74)$ \\
\hline \multirow[t]{2}{*}{ Sodium (mg/l) } & $69.63 \pm 9.40$ & $56.25 \pm 5.99$ & $52.42 \pm 6.22$ & $25.40 \pm 3.90$ & $50.93 \pm 9.28$ & $21.70 \pm 3.20$ & $15.30 \pm 4.89$ & $18.95 \pm 2.75$ & $5.23 \pm 0.58$ & $15.30 \pm 3.12$ \\
\hline & $(60.23-79.03)$ & $(50.26-62.24)$ & $(46.20-58.64)$ & $(21.50-29.30)$ & $(41.65-60.21)$ & $(18.50-24.90)$ & $(10.41-20.19)$ & $(16.20-21.70)$ & $(4.65-5.81)$ & $(12.18-18.42)$ \\
\hline
\end{tabular}


Table 4: Mean monthly values of the trace metal parameters of Obizi Stream and Iyiocha Stream compared with WHO standards for safe drinking water.

\begin{tabular}{llll}
\hline Parameters & Obizi Stream & Iyiocha Stream & Reference Value (WHO Std) (2003) \\
\hline Lead (mg/l) & $5.04 \pm 2.60$ & $0.21 \pm 0.04$ & $\leq 0.05$ \\
& $(2.44-7.64)$ & $(0.17-0.25)$ & \\
Copper (mg/l) & $1.16 \pm 0.56$ & $0.07 \pm 0.04$ & $\leq 1$ \\
& $(0.06-1.72)$ & $(0.02-0.10)$ & \\
Manganese (mg/l) & $0.17 \pm 0.07$ & $0.28 \pm 0.05$ & $\leq 0.05$ \\
& $(0.10-0.24)$ & $(0.23-0.33)$ & \\
Zinc (mg/l) & $1.59 \pm 0.51$ & $0.47 \pm 0.27$ & $\leq 5$ \\
& $(1.08-2.10)$ & $(0.20-0.74)$ & \\
Sodium (mg/l) & $50.93 \pm 9.28$ & $15.30 \pm 3.12$ & 5.00 \\
& $(41.65-60.21)$ & $(12.18-18.42)$ & \\
\hline
\end{tabular}

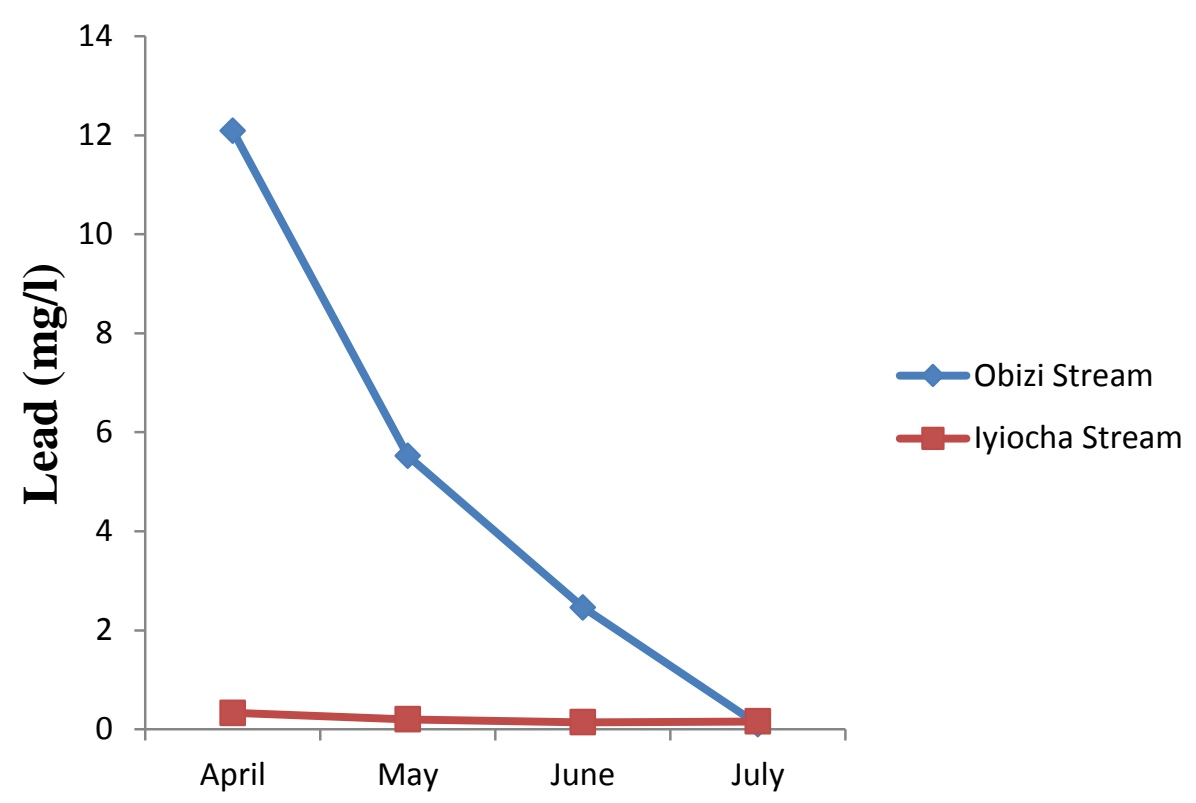

Figure 4: Mean monthly variations in lead in Obizi Stream and Iyiocha Stream.

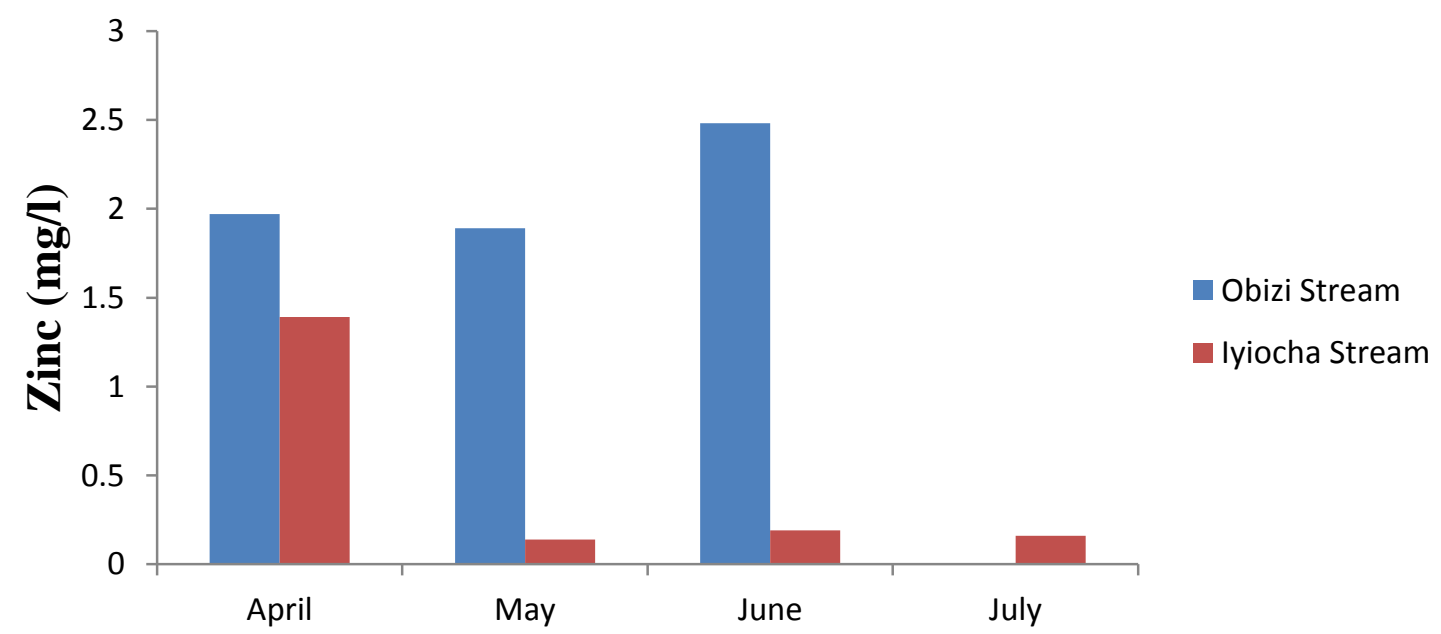

Figure 5: Mean monthly variations in zinc in Obizi Stream and Iyiocha Stream.

\section{DISCUSSION}

Maximum benefit is derived from water usage when it is within the accepted quality standards; however, where there are alterations in the water quality parameters and concentration of heavy metals, it is imperative that it goes through processes to improve quality prior to such usage, especially for drinking. For Obizi Stream, the $\mathrm{pH}$ was slightly acidic $(6.20 \pm 0.43)$. The low variability of $\mathrm{pH}$ values observed according to Hynes (1972), may be attributed to its resistance to $\mathrm{pH}$ changes due to chemical buffering effects. The $\mathrm{pH}$ value in Obizi Stream is above the $\mathrm{pH}$ value of Ogbei Stream 
(5.53 \pm 0.35$)$, (Ibemenuga and Inyang, 2003), but less than the ranges recorded in Anambra River (6.68 \pm 0.22$)$ (Odo, 2004). This may be due to the river's large volume of water in relation to the amount of dissolved organic matter in it compared with Obizi Stream. For natural water, the $\mathrm{pH}$ of 6.5-8.5 is required as recommended by WHO (2003) and this is in line with the $\mathrm{pH}$ values obtained in Iyiocha Stream. Hardness of the two streams was relatively high when compared to the WHO standard limit of $\leq 70 \mathrm{mg} / \mathrm{l}$ and this could be attributed to increased human activities such as swimming, farming, fermenting of cassava, washing of bitter leaf, breadfruit, bathing, etc in the study streams. Recent studies have confirmed the belief that increasing hardness in water is correlated with decreasing cardiovascular mortality in males (Lacey, 1981). Alkalinity of both streams was relatively low compared with the range $75 \mathrm{mg} / \mathrm{l}-200 \mathrm{mg} / \mathrm{l}$ considered to be productive water (Hem, 1970). Winger (1981) in his review on the physical and chemical characteristics of warm water reported that excessive land use in the catchment area influences the quality of substances entering receiving waters. The higher biochemical oxygen demand recorded in Obizi Stream may be due to human activities and organic materials entering the streams. BOD values indicate the extent of organic pollution in the aquatic systems which greatly reduce the water quality (Jonnalagadda and Mhere, 2001).

Lead content of both streams is higher than WHO standard of $\leq 0.05 \mathrm{mg} / \mathrm{l}$. Lead causes brain and nervous system retardation, increases blood pressure and impairs kidney in man (Hoekman, 2015). The level of manganese in both streams is below the value obtained from Aba River (0.25) (Amadi, 2010). Manganese has no nutritional value rather they are carcinogenic and bioaccumulate into toxic level to damage essential human and animal organs (Amadi et al., 2010). The value recorded in both streams for sodium content was above the WHO (2003) recommended limit of $5.00 \mathrm{mg} / \mathrm{l}$. Sodium makes drinking water salty and high ratio of $\mathrm{Na}$ ions to total cations harm permeability of agricultural soil (APHA, 1992).All other parameters tested for including turbidity, zinc and copper are within the WHO (2003) permissible limit. The concentration of these parameters above internationally acceptable drinking water quality standards renders aquatic bodies unsuitable for human consumption. In order to make this water safe for drinking, appropriate treatment procedures must be followed.

\section{CONCLUSION}

The results obtained showed that both streams differ in physico-chemical parameters and trace metal contents. Obizi Stream showed higher levels of most parameters measured and this can be attributed to more intensive anthropogenic activities around its catchment than Iyiocha Stream. There is therefore serious need to control activities around the streams to prevent harmful chemical contaminants which cause public health hazards.

\section{REFERENCES}

Amadi, A.N. (2010). Effects of urbanization on groundwater quality: A case study of Port-Harcourt, Southern Nigeria. Natural and Applied Sciences Journal, 11(2): 143-152.
American Public Health Association (1992). Standard Methods for Examination of Water and Wastewater. $18^{\text {th }}$ Edition. American Public Health Association, Washington, D.C., p. 1365

American Public Health Association (1995). Standard Methods for Examination of Water and Wastewater. $20^{\text {th }}$ Edition. American water work Association, Water Environment Federation, Washington, D.C.

American Public Health Association (1998). Standard Method for the Examination of Water and Wastewater. $18^{\text {th }}$ Edition. American Public Health Association, Washington, DC, Pp.45-60.

Anake, W.U., Nsikak, U.B., Anuoluwa, A.A., Ehi-Eromosele, C.O., Adeniyi, I.O. (2014). Assessment of trace metals in drinking water and groundwater sources in Ota, Nigeria. International Journal of Scientific and Research Publications, 4(5): 2250-3153.

Chitmanat, C. and Traichaiyaporn, I. (2010). Spatial and temporal variations of physico-chemical water quality and some heavy metals, in water sediments and fish of the Mae Kuang River, North Thailand. International Journal of Agriculture and Biology, 12 (6): 816-820

European Protection Agency (EPA) (1999). Drinking water and Health. Retrieved from http://www.doh.wa.gov/epa/water.htm. Assessed March 7, 2011.

Hem, J.D. (1970). Study and Interpretation of the Chemical Characteristics of Natural Water. $3^{\text {rd }}$ Edition. United States Government Printing Office, Alexandria, United States of America, Pp. 19-24.

Hoekman, B. and Mavroidis, P.C. (2015). Embracing diversity: Plurilateral agreements and the trading system. World Trade Review, 14(1): 101-116.

Hynes, H.B.N. (1975). The Stream and its valley, Verandiungung der Internationalen Vereinigung Fur. Theoretische and Angwanate Lininologie, 20:597.

Ibemenuga, K.N. and Inyang, N.M. (2003). Physico-chemical characteristics of a tropical Stream in Nigeria. Bio-Research, 5(2): 275-281.

Jonnalagadda, S.B. and Mhere, G. (2001). Water quality of the Odzi River in the eastern highlands of Zimbabwe. Water Research, 35 (5): 2371-2376.

Lacey, J. and Flamholtz, E.G. (1981). The implications of the economic theory of human capital for personnel management. Personnel Review, 10(1): 30-40.

Murray, W.E. (2013). The second wave of globalisation and agrarian change in the Pacific Islands. Journal of Rural Studies, 17(2): 135-148.

Nwodo, C.S., Nwinyi, C.O., Oluwadamisi, A.Y. and Eze, N.V. (2011). Assessment of water quality in Canaanland, Ota, Southwest Nigeria. Agriculture and Biology Journal of North America, 2(4): 577-583.

Odo, G.E. (2004). Studies on the ecology of macro invertebrate fauna as fish food in Anambra river basin, Nigeria. Ph.D. Thesis. University of Nigeria, Nsukka, Nigeria. p. 192. 
Ojutiku, R.O., Ibrahim, A. and Raymond, A. (2014). Assessment of water quality parameters and trace metal contents of drinking water sources in Minna Metropolis, Niger State. International Journal of Current Microbiology and Applied Science, 3(5): 1029-1037.

Rail, C.D. (2000). Groundwater Contamination, Volume 1:Contamination, sources and hydrology. Technomic Publishing Company, Lancaster, Pennysylvania. 187pp.
Wetzel, R.G. (1975). Limnology. W.B. Saunders Company, London. 783pp.

Winger, P.V. (1981). Physical and chemical characteristics of warm water Streams: A Review. African Journal of Ecology, 43(1): 7-13.

World Health Organization (2003). Guidelines for drinking-water quality. $3^{\text {rd }}$ Edition. WHO Press, Geneva, Switzerland. Pp. 20-24.

\section{$\underline{\text { How to cite this article }}$}

Ibemenuga, K.N. and Egbosi, C.C. (2018). An Assessment of Water Quality Parameters and Trace Metal Contents of Two Surface Drinking Water in Nise, Anambra State, Nigeria. Tropical Journal of Applied Natural Sciences, 2(2): 64-72. Doi: https://doi.org/10.25240/TJANS.2018.2.2.09. 